\section{Effects of Reclaimed Water Irrigation on Growth and Nitrogen Uptake of Turfgrass}

\author{
Jinghua Fan ${ }^{1,3,6}$, George Hochmuth ${ }^{1,4,6}$, Jason Kruse ${ }^{2,5}$, and \\ Jerry Sartain ${ }^{1,4}$
}

ADDITIONAL INDEX WORDs. N leaching, nutrient, turf fertilizer, water quality, water reuse

SUMMARY. Reclaimed water (RW) is increasingly viewed as a valuable resource for supplying irrigation water and nutrients for landscape plants growing in urban environments. A greenhouse experiment was conducted to determine if nitrogen (N) in RW contributes significantly to turfgrass plant nutrition and to measure $\mathrm{N}$ use efficiency and the effects of irrigation with RW on $\mathrm{N}$ leaching. The factorial experiment was replicated four times and conducted in a greenhouse on the University of Florida campus for 1 year using 'Floratam' st. augustinegrass (Stenotaphrum secundatum) and 'Empire' zoysiagrass (Zoysia japonica). Treatments included irrigation with tap water (control), irrigation with RW from University of Florida wastewater treatment facility, irrigation with $\mathrm{RW}$ with additional $\mathrm{N}$ supplied from ammonium nitrate to achieve 5,9 , and $13 \mathrm{mg} \cdot \mathrm{L}^{-1} \mathrm{~N}$ solutions, and a dry prilled fertilizer treatment based on the recommended $\mathrm{N}$ application rate for turfgrass in northern Florida. The average total $\mathrm{N}$ and phosphorus $(\mathrm{P})$ concentrations of RW, based on 1 year weekly monitoring were $3.31 \mathrm{mg} \cdot \mathrm{L}^{-1}$ total $\mathrm{N}$ with $2.14 \mathrm{mg} \cdot \mathrm{L}^{-1}$ nitrate- $\mathrm{N}$ and $0.46 \mathrm{mg} \cdot \mathrm{L}^{-1}$ ammonium- $\mathrm{N}$, and $2.00 \mathrm{mg} \cdot \mathrm{L}^{-1} \mathrm{P}$ composed of $1.92 \mathrm{mg} \cdot \mathrm{L}^{-1}$ orthophosphate. Turfgrass growth responded positively $(P<0.05)$ to $\mathbf{N}$ concentration in the irrigation water. The concentration of $\mathrm{N}$ in the unamended university campus RW was not sufficient for optimal turfgrass growth. Grass quality and turfgrass clippings yield maximized when the total $\mathrm{N}$ concentration in the irrigation water was at least $5 \mathrm{mg} \cdot \mathrm{L}^{-1}$. Turfgrass receiving dry synthetic $\mathbf{N}$ fertilizer resulted in greater growth and 2 -fold greater $\mathbf{N}$ leaching than with the remaining treatments for both turf types. The highest $\mathbf{N}$ recovery percentage for both turf types was found when the $\mathrm{N}$ concentration in the solution was $5 \mathrm{mg} \cdot \mathrm{L}^{-1}$.

S evere competition for water resources is predicted as the population continues to grow in southern United States (O'Connor et al., 2008; Sun et al., 2008). The continued availability of inexpensive potable water for irrigation is in question. Further, the price of fertilizers has been increasing over the last decade. In 2010, the fertilizer price index in the United States was 5 -fold higher than that in 1960 (U.S. Department of Agriculture, 2010). Under this scenario,

This research was, in part, supported through a grant (contract no. WM969) from the Florida Department of Environmental Protection and the St. Johns River Water Management District.

We thank Ms. Dawn Lucas and students in Soil and Water Science Department, University of Florida, for their assistance in chemical analysis.

${ }^{1}$ Soil and Water Science Department, University of Florida, Gainesville, FL 32611-0290

${ }^{2}$ Environmental Horticulture Department, University of Florida, Gainesville, FL 32611

${ }^{3}$ Postdoctoral Associate

${ }^{4}$ Professor

${ }^{5}$ Assistant Professor

${ }^{6}$ Corresponding author. E-mail: jfan@ufl.edu or hoch@ ufl.edu. the use of reclaimed wastewater is increasingly viewed as a resource for supplying irrigation water and nutrients for landscapes (Harivandi, 2004). Reclaimed water contains nutrients, such as $\mathrm{N}$ and $\mathrm{P}$, which are essential plant nutrients. Currently, Florida is a leading user of RW with more than $50 \%$ of the state's RW going to irrigation of recreational areas, including golf courses, parks, athletic fields, and residential landscapes (Toor and Rainey, 2009).

Most of the studies with RW have focused on the detrimental effects of soluble salts on plant growth and soil quality, groundwater enrichment of $\mathrm{N}$ and $\mathrm{P}$, and environmental protection strategies (Kalavrouziotis et al., 2008; Maurer et al., 1995; Pedrero and Alarcon, 2009; Thomas et al., 2006; Wang et al., 2003; Xu et al., 2009, 2010). Pereira et al. $(2011,2012)$ found plant nutrients and nonessential elements tended to accumulate in the soil after 11 years of RW irrigation. Therefore, seasonal and annual $\mathrm{N}$ fertilization amounts should be adjusted when nutrients in the irrigation source may contribute to the nutritional needs of plants (Carrow, 2012). Hayes et al. (1990a,b) demonstrated that the use of wastewater effluent to supply adequate water for bermudagrass (Cynodon dactylon) growth in Arizona also resulted in increased concentrations of soil nitrate. King and Balogh (1999) were able to significantly decrease off-site nitrate- $\mathrm{N}$ transport, with a resulting improvement in water quality, by reducing the application rates of fertilizers as irrigation rates were increased. In a multiyear irrigation study continuous use of saline irrigation water without flushing of salts by rainfall resulted in accumulation of salts in the soil to a level detrimental to turfgrass health (Evanylo et al., 2010). However, such an effect depends on soil type, grass type, and climate. Sevostianova et al. (201la,b) documented no negative effects from saline irrigation and salt

\begin{tabular}{llll}
\hline $\begin{array}{l}\text { Units } \\
\text { To convert U.S. to SI, } \\
\text { multiply by }\end{array}$ & U.S. unit & SI unit & $\begin{array}{l}\text { To convert SI to U.S., } \\
\text { multiply by }\end{array}$ \\
\hline 29.5735 & $\mathrm{fl} \mathrm{oz}$ & $\mathrm{mL}$ & 0.0338 \\
2.54 & inch(es) & $\mathrm{cm}$ & 0.3937 \\
25.4 & inch $(\mathrm{es})$ & $\mathrm{mm}$ & 0.0394 \\
6.4516 & inch & $\mathrm{cm}$ & 0.1550 \\
48.8243 & $1 \mathrm{~b} / 1000 \mathrm{ft}^{2}$ & $\mathrm{~kg} \cdot \mathrm{ha}^{-1}$ & 0.0205 \\
1.1209 & $\mathrm{~b} / \mathrm{acre}$ & $\mathrm{kg} \cdot \mathrm{ha}^{-1}$ & 0.8922 \\
1 & $\mu \mathrm{mho} / \mathrm{cm}$ & $\mu S \cdot \mathrm{cm}^{-1}$ & 1 \\
1 & $\mathrm{mmho} / \mathrm{cm}$ & $\mathrm{dS} \cdot \mathrm{m}^{-1}$ & 1 \\
28.3495 & $\mathrm{oz}$ & $\mathrm{g}$ & 0.0353 \\
28,350 & $\mathrm{oz}$ & $\mathrm{mg}$ & $3.5274 \times 10^{-5}$ \\
7.0053 & $\mathrm{oz} / \mathrm{acre}$ & $\mathrm{mg} \cdot \mathrm{m}^{-2}$ & 0.1427 \\
33.9057 & $\mathrm{oz} / \mathrm{yard}$ & $\mathrm{g} \cdot \mathrm{m}^{-2}$ & 0.0295 \\
1 & $\mathrm{ppb}$ & $\mu \mathrm{g} \cdot \mathrm{L}^{-1}$ & 1 \\
0.001 & $\mathrm{ppm}$ & $\mathrm{mg} \cdot \mathrm{g}^{-1}$ & 1000 \\
1 & $\mathrm{ppm}$ & $\mathrm{mg} \cdot \mathrm{kg}^{-1}$ & 1 \\
1 & $\mathrm{ppm}$ & $\mathrm{mg} \cdot \mathrm{L}^{-1}$ & 1 \\
$\left({ }^{\circ} \mathrm{F}-32\right) \div 1.8$ & ${ }^{\circ} \mathrm{F}$ & ${ }^{\circ} \mathrm{C}$ & $\left({ }^{\circ} \mathrm{C} \times 1.8\right)+32$ \\
& & &
\end{tabular}


accumulation for several warm-season grasses. Micronutrients supplied in RW accumulated to excessive concentrations in plants. Micronutrients, such as boron (B) and copper $(\mathrm{Cu})$, supplied in RW tended to be excessive for plants (Pereira et al., 2011) and heavy metals were a concern (Exall et al., 2004).

There are three stages of wastewater treatment: primary, secondary, and advanced. Reclaimed water is wastewater that has received at least secondary treatment. The main difference between RW that has received secondary versus advanced treatment is the reduced level of nutrients and other chemicals remaining in water subjected to advanced treatment. Water receiving advanced treatment typically has $25 \%$ of the $\mathrm{N}$ and $\mathrm{P}$ and less soluble salts than contained in secondary treated RW (Asano et al., 2007). Increasingly, RWs used for irrigation are from advanced wastewater treatment facilities. As the production of $\mathrm{RW}$ increases, there is more interest in using RW to irrigate residential lawns. Using RW to supply a portion of the $\mathrm{N}$ for turfgrass growth may allow reductions in amounts of other $\mathrm{N}$ fertilizer sources used. It is important to determine the optimum combinations of water and nutrient applications to support turfgrass production without impairing groundwater through losses of nutrients from the landscape (Petrovic, 1990). However, few studies have focused on the degree to which residential turfgrass can use the $\mathrm{N}$ from RW following advanced treatment.

St. augustinegrass and zoysiagrass are the most common residential turf species in Florida. Nitrogen applications to turfgrass occur more frequently and in larger quantities than any other fertilizer-supplied nutrient because $\mathrm{N}$ is typically the most growth-limiting nutrient in turfgrass (Hochmuth et al., 2009). Current N fertilization recommendations for st. augustinegrass and zoysiagrass in Florida include a range of rates from 98 to $294 \mathrm{~kg} \cdot \mathrm{ha}^{-1} \mathrm{~N}$ annually, depending on geographical region in the state and level of aesthetic preference (Trenholm et al., 2012). The typical $\mathrm{N}$ fertilizer application rate was $195 \mathrm{~kg} \cdot \mathrm{ha}^{-1} \mathrm{~N}$ (about $4 \mathrm{lb} / 1000 \mathrm{ft}^{2} \mathrm{~N}$ ) annually for both turf types in the northern Florida area. Greenhouse studies were conducted using these two most common turfgrass types to determine if $\mathrm{N}$ from $\mathrm{RW}$ played a significant role in turfgrass nutrition. The goal of this research project was to determine if there is a fertilizer offset (a deduction that can be made in fertilizer $\mathrm{N}$ use) when RW containing $\mathrm{N}$ is used to irrigate turfgrass. Specifically, the objectives were (1) to compare the effects of RW-derived $\mathrm{N}$ and fertilizer- $\mathrm{N}$ on turfgrass growth and health, (2) to measure nutrient use efficiency of turfgrass with various $\mathrm{N}$ treatments, and (3) to evaluate the potential $\mathrm{N}$ leaching loss to the environment associated with various $\mathrm{N}$ treatments.

\section{Materials and methods}

SAND, RW, AND TURFGRASS SOURCES. Experiments were conducted in Envirotron greenhouse at the Environmental Horticulture Department on the campus of the University of Florida, Gainesville. Sand (obtained from a commercial sand quarry in Ocala, FL) was used for the media for these greenhouse studies conducted from July 2011 to Aug. 2012. Sand was used because it represents soils common in Florida. The chemical properties of the sand media are presented in Table 1 . The sand was very low in $\mathrm{N}$ such that $\mathrm{N}$ in the unfertilized media would contribute little to plant growth and $\mathrm{N}$ would need to be supplied from the specific $\mathrm{N}$ treatments. Reclaimed water was supplied from a tap in the Envirotron greenhouse from the campus wastewater utility that uses advanced treatment. Chemical properties of the RW are presented in Table 2. Irrigation solutions were prepared in the greenhouse using RW or tap water and were stored in dark tanks on-site during the study period.

Inside the greenhouse, computer controlled end-wall exhaust fans, a wall-length evaporative-cooling pad humidifier, and an automatic roof vent were used to maintain environmental conditions. Greenhouse air temperature was maintained at an average $24 \pm$ $6{ }^{\circ} \mathrm{C}$, and relative humidity was maintained between $50 \%$ and $75 \%$ over the experimental period.

'Floratam' st. augustinegrass and 'Empire' zoysiagrass sods were supplied from a commercial sod farm in central Florida. Roots of all sods were washed with a tap water spray nozzle to remove residual soil and associated fertilizer nutrients and the sod pieces

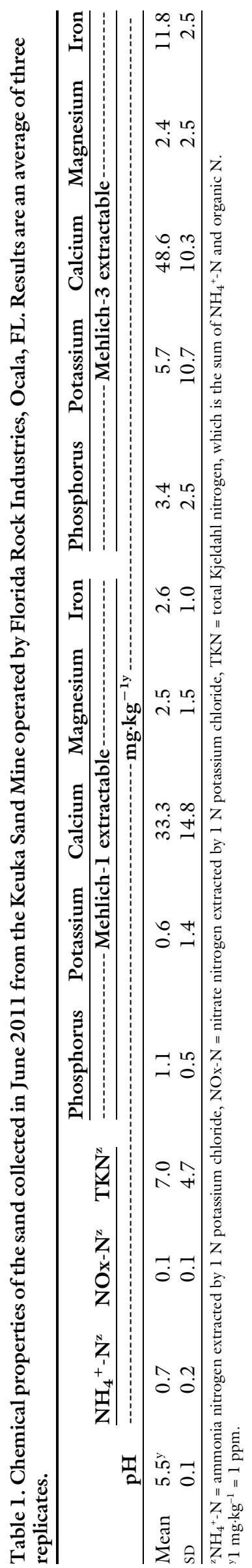

Horllechnology • October 2014 24(5) 


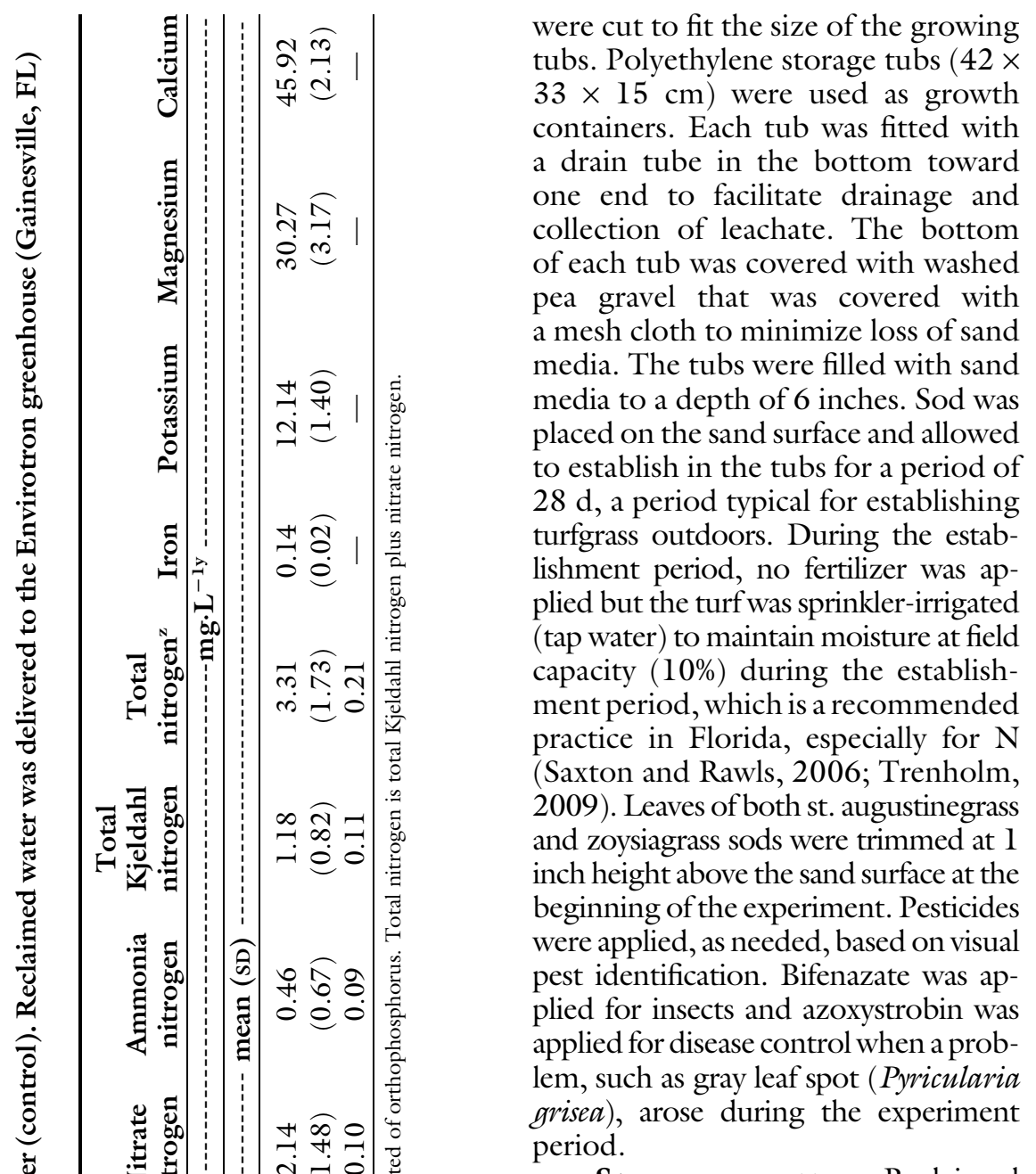

SAMPLE COLlection. Reclaimed water samples were collected at the greenhouse tap and were analyzed for electrical conductivity (EC), $\mathrm{pH}, \mathrm{N}$ [nitrate $\mathrm{N}\left(\mathrm{NO}_{3}-\mathrm{N}\right)$, total Kjeldahl-N (TKN), ammonia $\left.\mathrm{N}\left(\mathrm{NH}_{4}-\mathrm{N}\right)\right]$, total $\mathrm{P}$, orthophosphate (ortho-P), iron $(\mathrm{Fe})$, magnesium $(\mathrm{Mg})$, potassium $(\mathrm{K})$, and calcium $(\mathrm{Ca})$ concentrations weekly. Two samples were collected during each sampling event with 30 -min time interval. Tap water samples were similarly collected once per month and analyzed for the same parameters.

Turfgrass color, as determined by chlorophyll content was measured bimonthly by a reflectance chlorophyll meter (Field Scout CM-1000; Spectrum Technologies, Plainfield, IL). Measurements were conducted under natural light conditions and the instrument was calibrated before use following the procedures recommended by manufacturer.

Turfgrass in each tub was trimmed with scissors in fall (6 Sept., 20 Sept., 11 Oct. 2011), spring (27 Feb., 2 May, 5 June 2012), and summer ( 5 and 20
Aug. 2012) to maintain turf at the recommended mowing height (3 inches from soil surface for st. augustinegrass and 2 inches for zoysiagrass). All tissue samples were dried until constant weight at $65^{\circ} \mathrm{C}$. Dried samples were weighed and ground in a Wiley mill to pass a $2-\mathrm{mm}$ screen. For each experimental unit (tub), dried and ground dry matter from all harvest dates in each harvest period (fall, spring, and summer) was combined and thoroughly mixed. For example, in the fall, each experimental unit had dry matter composited from three harvests. The mixed composited dry matter was sampled for laboratory tissue analyses. This process was repeated for the spring and summer harvest periods. At the end of the experiment (Aug. 2012), all final plant parts (roots and verdure) and thatch were harvested from a 3 inches wide slice of media in each tub simultaneous with the final clippings harvest. Verdure samples included the stolons and leaf blades remaining after the clippings were removed. Thatch samples consisted of all dead plant material above the soil surface after verdure was removed. Roots were washed free of media. Soil adhering to the tissue samples was removed by gentle washing with tap water.

SAMPLE ANALYsis. Water samples (RW, tap water, and leachate) were immediately preserved on ice to maintain a sample temperature of $<4{ }^{\circ} \mathrm{C}$ and delivered same day they were collected to the University of Florida Institute of Food and Agricultural Sciences Analytical Research Laboratory for analysis. The concentrations of $\mathrm{NO}_{3}-\mathrm{N}, \mathrm{NH}_{4}-\mathrm{N}$, and $\mathrm{TKN}$ were determined using a discrete autoanalyzer following U.S. Environmental Protection Agency (USEPA) method 351.2 (USEPA, 1993a). Total $\mathrm{N}$ was calculated as the sum of TKN and $\mathrm{NO}_{3}-\mathrm{N}$. The concentrations of total $\mathrm{P}$ and ortho-P were determined by the molybdenum-blue method after digestion with acidified ammonium persulfate following USEPA method 365.1 (USEPA, 1993b). The concentrations of dissolved macro- and microelements in water were determined using an inductively coupled plasma emission spectrometer (ICP) following USEPA method 200.7 (USEPA, 1994).

Soil samples were air-dried, ground using a mortar to break up clumps, and 
passed through a $2-\mathrm{mm}$ sieve before chemical analyses. Soil $\mathrm{N}\left(\mathrm{NH}_{4}-\mathrm{N}\right.$ and $\mathrm{NO}_{3}-\mathrm{N}$ ) was determined by shaking a $2.5 \mathrm{~g}$ air-dried soil sample in 25 $\mathrm{mL}$ of $2 \mathrm{M}$ potassium chloride for $1 \mathrm{~h}$. Concentrations of $\mathrm{NH}_{4}-\mathrm{N}$ and $\mathrm{NO}_{3}{ }^{-}$ $\mathrm{N}$ in the filtrate were determined with a discrete autoanalyzer. Total Kjeldahl $\mathrm{N}$ was determined from a $\mathrm{l}-\mathrm{g}$ soil sample digested with $2.0 \mathrm{~g}$ of Kjeldahl mixture and concentrated $(12 \mathrm{M})$ sulfuric acid solution in an aluminum block digester for $\mathrm{l} \mathrm{h}$ followed by semiautomated colorimetric analysis (USEPA method 351.2). Concentrations of soil available $\mathrm{P}$ and metals were determined by two extraction methods: (1) Mehlich-1 (1:4 ratio of soil/0.05 $M$ hydrochloric acid + $0.0125 \mathrm{M}$ sulfuric acid; 5 -min reaction time) and (2) Mehlich-3 [1:10 ratio of soil/Mehlich-3 extraction solution (0.2 $\mathrm{M}$ acetic acid $+0.25 \mathrm{M}$ ammonium nitrate $+0.015 \mathrm{M}$ ammonium fluoride $+0.013 \mathrm{M}$ nitric acid +0.001 $\mathrm{M}$ ethylenediaminetetraacetic acid, $\mathrm{pH}$ 2.0); 5-min reaction time] (Mehlich, 1984). At the end of extractions, the supernatant was filtered before being analyzed by the ICP (USEPA method 200.7).

The plant samples were dried at $65^{\circ} \mathrm{C}$ for $72 \mathrm{~h}$ and ground in a Wiley Mill to pass a 2 -mm screen. Total Kjeldahl $\mathrm{N}$ concentration in plant tissue was determined from a $0.2 \mathrm{-g}$ ground plant sample digested with $2.0 \mathrm{~g}$ of Kjeldahl mixture and concentrated $(12 \mathrm{M})$ sulfuric acid solution in an aluminum block digester for $\mathrm{l} \mathrm{h}$ followed by semiautomated colorimetric analysis (USEPA method 351.2).

Experimental Design. The experimental design was a factorial experiment in a randomized complete block design with four replications. The first factor consisted of two turf types: st. augustinegrass and zoysiagrass, and the second factor consisted of six $\mathrm{N}$ fertilizer treatments, tap water control, RW containing the base level $\mathrm{N}$ in the delivered $\mathrm{RW}, \mathrm{RW}$ with additional 2,6 , and $10 \mathrm{mg} \cdot \mathrm{L}^{-1} \mathrm{~N}$, and a dry synthetic fertilizer control. All solutions involving RW began with the delivered $\mathrm{RW}$ with $3 \mathrm{mg} \cdot \mathrm{L}^{-1}$ $\mathrm{N}$, which is a mixture of $\mathrm{NO}_{3}-\mathrm{N}$ and $\mathrm{NH}_{4}-\mathrm{N}$ with a fluctuating $\mathrm{NO}_{3}-\mathrm{N}$ : $\mathrm{NH}_{4}-\mathrm{N}$ ratio. Then additional $\mathrm{N}$ was added in the form of ammonium nitrate to increase the final delivered $\mathrm{N}$ concentrations to 5,9 , and $13 \mathrm{mg} \cdot \mathrm{L}^{-1} \mathrm{~N}$.
Media testing for $\mathrm{P}$ and $\mathrm{K}$ showed very low concentrations so $\mathrm{P}, \mathrm{K}$, and other macro- and micronutrients were added in the nutrient solution. Concentrations of major nutrients other than $\mathrm{N}(\mathrm{P}, \mathrm{K}$, $\mathrm{Ca}, \mathrm{Mg}$ ) and minor nutrients $[\mathrm{B}, \mathrm{Cu}$, manganese $(\mathrm{Mn})$, molybdenum $(\mathrm{Mo})$, zinc $(\mathrm{Zn})]$ were the same across all the treatments and supplied from a separate nutrient stock added to each $\mathrm{N}$ treatment irrigation solution. All turfgrass received the same amount of these nutrients in water-soluble forms at levels recommended to prevent deficiencies of these nutrients. Turf fertilized with the recommended synthetic fertilizer treatment received the equivalent of $195 \mathrm{~kg} \cdot \mathrm{ha}^{-1} \mathrm{~N}$ per year (about $0.227 \mathrm{~g} /$ tub N per month) in the form of dry ammonium nitrate $(0.66 \mathrm{~g})$ monthly. A zero- $\mathrm{N}$ control treatment was included where turfgrass was irrigated with tap water only.

The amount of irrigation to apply daily was determined as the amount needed to maintain the media at field capacity allowing negligible leaching. A typical irrigation rate was $300 \mathrm{~mL} /$ tub per day (about $2 \mathrm{~mm}$ per day). The application frequency was evaluated and adjusted every $3 \mathrm{~d}$ based on turf growth and weather. The irrigation frequency was $4 \mathrm{~d}$ per week in December and March, $3 \mathrm{~d}$ per week in January and February, and $7 \mathrm{~d}$ per week in the rest of the months of the year.

Near the end of the experiment in Aug. 2012 two leaching events were carried out (to simulate a leaching event) by applying $1000 \mathrm{~mL}$ tap water to each growing tub manually the week after the final nutrient application and then 2 weeks later. Leachate was collected from the bottom drainage port of each tub. The leachate volume was measured and a subsample was immediately delivered to the laboratory for determination of $\mathrm{NO}_{3}-\mathrm{N}, \mathrm{TKN}$, and $\mathrm{NH}_{4}-\mathrm{N}$ concentrations. Leachate $\mathrm{N}$ loads were determined by multiplying the $\mathrm{N}$ concentration in the leachate from each tub by the leachate volume.

Quality Control. All sample collection, handling, and chemical analyses were conducted according to the National Environmental Laboratory Accreditation Conference standards at the University of Florida Analytical Research laboratory under certification number Florida Department of Health E72850. Method reagent blanks, spike samples, as well as certified standards from a source other than normal calibration standards, were included in the digestion or extraction process for every 20 samples. Percentage recovery of $\mathrm{N}$ ranged from $95 \%$ to $105 \%$, meeting quality control standards for the project.

Statistical analyses. Significance of interaction and treatment effects was determined by analysis of variance (F test was significant at $P<$ 0.05 ) using SAS (version 9.1 for Windows; SAS Institute, Cary, NC). Fisher's least significant difference values were used to determine the differences among the treatment means at the $0.05 P$ level.

\section{Results and discussion}

RECLAIMED WATER CHARACTERIZATION AND MONITORING. The $\mathrm{pH}$ of RW was stable during the year with an average of 7.14 (Table 2). The EC, a measure of salinity in the water, was $0.63 \mathrm{dS} \cdot \mathrm{m}^{-1}$, which is lower than that reported previously by Pedrero and Alarcon (2009) of $2.8 \mathrm{dS} \cdot \mathrm{m}^{-1}$ and by Evanylo et al. (2010) of 1.5 $\mathrm{d} S \cdot \mathrm{m}^{-1}$. A critical EC level $(50 \%$ inhibition of growth) for warm season turfgrasses irrigation has been estimated to be below $3 \mathrm{dS} \cdot \mathrm{m}^{-1}$ (Carrow and Duncan, 1998). Thus, the $\mathrm{pH}$ and EC of the RW in this study would not be expected to adversely affect turfgrass growth.

The University of Florida wastewater treatment facility uses the "biodenipho" process for wastewater treatment that involves alternating aerated and anoxic conditions to promote exit of $\mathrm{N}$ by denitrification. $\mathrm{N}$ concentrations of RW during 1 year are presented in Fig. 1. $\mathrm{NO}_{\mathrm{x}}-\mathrm{N}, \mathrm{NH}_{4}{ }^{-}$ $\mathrm{N}$, and TKN concentrations were in the range of 0.06 to $6.16 \mathrm{mg} \cdot \mathrm{L}^{-1}$, 0.03 to $3.07 \mathrm{mg} \cdot \mathrm{L}^{-1}$, and 0.35 to 5.06 $\mathrm{mg} \cdot \mathrm{L}^{-1}$, respectively. The maximum total $\mathrm{N}$ concentration (sum of $\mathrm{NO}_{\mathrm{x}^{-}}$ $\mathrm{N}$ and TKN) appeared on 19 Jan. 2012 at $11.22 \mathrm{mg} \cdot \mathrm{L}^{-1}$. Total $\mathrm{N}$ concentrations of samples collected from all the other dates were less than 6.41 $\mathrm{mg} \cdot \mathrm{L}^{-1}$ (Fig. 1). Average concentrations of nutrients in RW, based on l-year monitoring, are presented in Table 2. The average $\mathrm{N}$ concentrations of RW, based on 1-year weekly monitoring from the start of this research in July 2011 , were $3.31 \mathrm{mg} \cdot \mathrm{L}^{-1}$ total $\mathrm{N}$ with $2.14 \mathrm{mg} \cdot \mathrm{L}^{-1}$ nitrate $\mathrm{N}$ and $0.46 \mathrm{mg} \cdot \mathrm{L}^{-1}$ ammonia $\mathrm{N}$. The 
concentrations of the same constituents in tap water and deionized water are also included (Table 2). The total $\mathrm{N}$ concentrations of RW were 17 times the concentrations in tap water. There was no specific pattern for concentrations of all species of $\mathrm{N}$ during the monitoring period (Fig. 1). Concentrations of $\mathrm{N}$ in the source RW varied; therefore should be sampled over any experimental period. It was impossible to vary the treatment concentrations of $\mathrm{N}$ to follow the changes in concentrations over the year. Therefore, we chose to use the average value of $3 \mathrm{mg} \cdot \mathrm{L}^{-1}$ total $\mathrm{N}$ as the base concentration of $\mathrm{N}$ for the treatments involving RW.

RESPONSE OF TURF QUALITY AND CLIPPINGS YIELDS. The results of chlorophyll index measurements are presented in Fig. 2. There was no interaction of turf type and $\mathrm{N}$ treatment for effects on turfgrass quality or clippings yield. St. augustinegrass receiving tap water and unamended RW

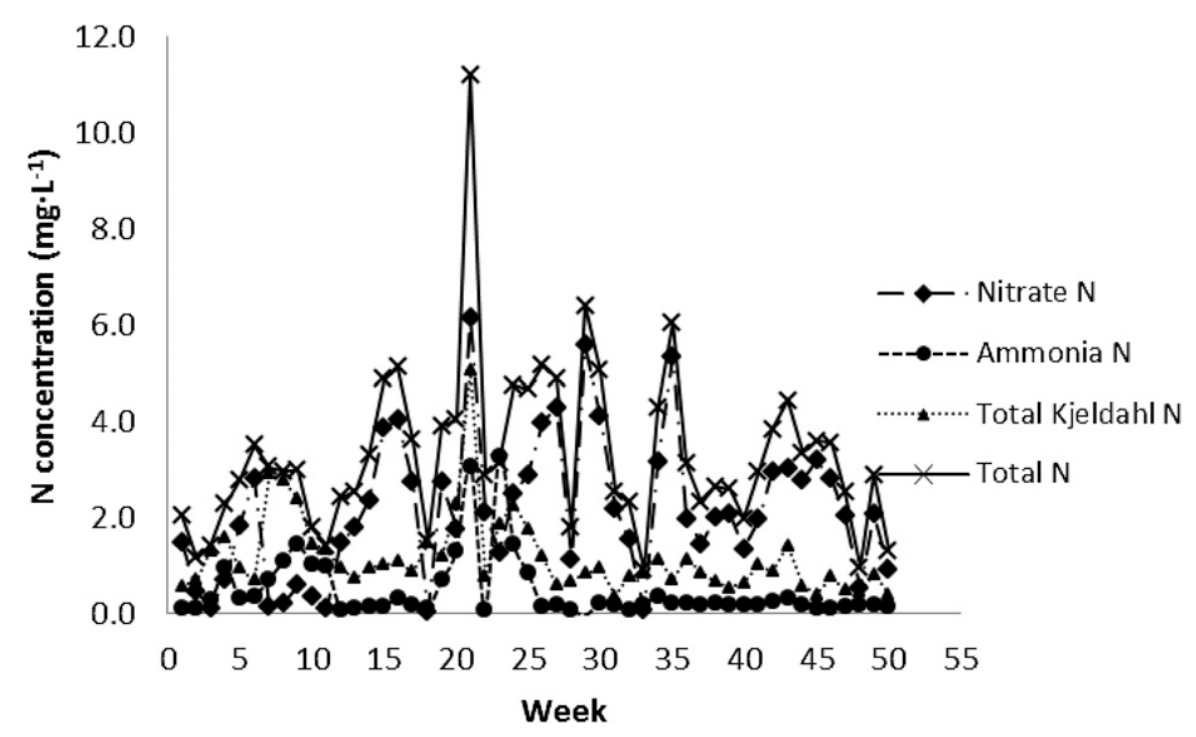

Fig. 1. Changes in concentrations of nitrogen $(\mathrm{N})$ species in reclaimed water at the Envirotron greenhouse (Gainesville, FL) during 1 year [started from 18 July 2011 (week 0)]; $1 \mathrm{mg} \cdot \mathrm{L}^{-1}=1 \mathrm{ppm}$. and zoysiagrass receiving tap water had chlorophyll index levels less than 150 (Fig. 2). The chlorophyll index measurements with the remaining treatments were above 150, which could be indicative of turf quality that is visually acceptable. This result is consistent with Rowland et al. (2010) that turf chlorophyll index measured with the same method met the minimum acceptable visual quality requirement when above 146. The chlorophyll index could be used as indicator of turfgrass quality and soil cover. This is supported by previous studies that found correlations between chlorophyll index and turfgrass clipping yield, leaf hue, darkness, and density (Rowland et al., 2010). Chlorophyll level is also closely related to the leaf $\mathrm{N}$ nutrition status; higher chlorophyll levels occurred with the higher $\mathrm{N}$ rates (Errecart et al., 2012). The chlorophyll level could likely be used as an indicator of $\mathrm{N}$ status to optimize $\mathrm{N}$ inputs (Kruse et al., 2006). Low growth rate and lightly colored leaves were observed on turfgrass with the lower $\mathrm{N}$ treatments (less than $5 \mathrm{mg} \cdot \mathrm{L}^{-1}$ $\mathrm{N}$ ), which indicated $\mathrm{N}$ deficiency.

Plant dry matter yields were affected by turf type and $\mathrm{N}$ treatment (Table 3). Zoysiagrass accumulated more dry matter than st. augustinegrass. The verdure, thatch, and root dry matter were greater for zoysiagrass than st. augustinegrass (Table 3 ). Bowman et al. (2002) found
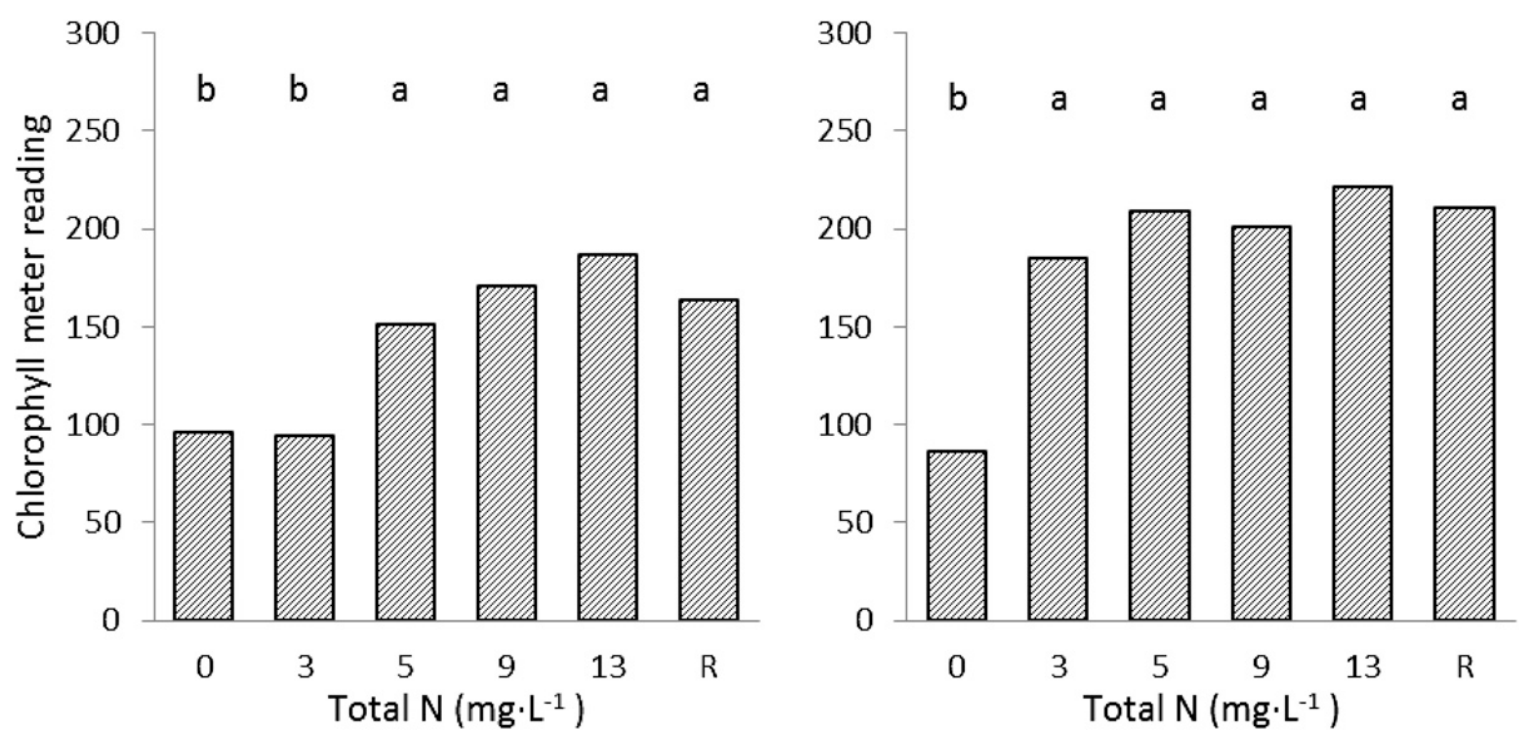

Fig. 2. Turfgrass chlorophyll level under different fertilizer treatments for st. augustinegrass (left) and zoysiagrass (right). Letter " $R$ " for nitrogen $(N)$ treatment refers to a dry fertilizer treatment based on the recommended $N$ application rate for turfgrass in northern Florida. Values are averages of three measurements for each treatment. Means with the same letters are not significantly different by Fisher's least significant difference $0.05 ; 1 \mathrm{mg} \cdot \mathrm{L}^{-1}=1 \mathrm{ppm}$. 
greater root weight for st. augustinegrass than zoysiagrass. The dry weight of turfgrass clippings each season as a function of irrigation solution $\mathrm{N}$ level can be described by a quadratic model, increasing with $\mathrm{N}$ treatment to $9 \mathrm{mg} \cdot \mathrm{L}^{-1}$ of $\mathrm{N}$, then leveling off. The dry weight of clippings for turf with the recommended $\mathrm{N}$ fertilizer was similar to dry weight with the RW $\mathrm{N}$ treatment of $9 \mathrm{mg} \cdot \mathrm{L}^{-1}$ or above in the spring and fall seasons. The clippings dry matter was greater with the synthetic fertilizer treatment in the summer. N supply from unamended RW for the period of most rapid growth (summer) was not sufficient to maximize clippings yield.

The desired turfgrass growth minimizes clipping yield (minimizes mowing frequency) while achieves acceptable turfgrass quality (Carrow, 2012). The results for turfgrass growth and quality indicated that irrigation treatments with RW greater than or equal to 5 in the spring or summer and $9 \mathrm{mg} \cdot \mathrm{L}^{-1}$ in the fall could avoid excessive growth with acceptable turf quality. These results were from turfgrass growing in containers requiring frequent irrigation and would need to be confirmed in outdoor studies.

There was no interaction of $\mathrm{N}$ treatment and turfgrass species for effects on $\mathrm{N}$ concentration in clippings (Table 4 ). Nitrogen treatment affected the TKN concentrations of plant parts each season: clippings $(P<$ $0.01)$, thatch $(P<0.05)$, and verdure $(P<0.01)$, whereas the TKN concentration in roots was unaffected by $\mathrm{N}$ treatment (Table 4). TKN concentration of clippings increased linearly with $\mathrm{N}$ level in the irrigation solution. There were no differences in tissue $\mathrm{N}$ concentration between the recommended $\mathrm{N}$ fertilizer treatment and treatments with 9 and $13 \mathrm{mg} \cdot \mathrm{L}^{-1} \mathrm{~N}$ from RW. This result shows that the treatments with $\mathrm{N}$ above $9 \mathrm{mg} \cdot \mathrm{L}^{-1}$ had the same effect on turf tissue $\mathrm{N}$ concentration as the recommended synthetic $\mathrm{N}$ fertilizer. Clippings from st. augustinegrass had greater $\mathrm{N}$ concentrations than zoysiagrass in the fall season. Clippings from zoysiagrass had greater $\mathrm{N}$ concentration than st. augustinegrass in the spring season, and concentrations were similar in the summer. The sufficient tissue $\mathrm{N}$ concentration range is $1.5 \%$ to $3.5 \%$ for these turfgrasses (Sartain, 2001).

Total plant $\mathrm{N}$ uptake was calculated as the product of tissue $\mathrm{N}$ concentration and dry weight for all parts of turfgrass and then summed over plant parts (clippings, verdure, thatch, and root). The total $\mathrm{N}$ uptake by turfgrass was affected by $\mathrm{N}$ treatments (Fig. 3). The treatments with applied $\mathrm{N}$ of 9 and $13 \mathrm{mg} \cdot \mathrm{L}^{-1}$ had the same effect on turf $\mathrm{N}$ uptake as the recommended $\mathrm{N}$ fertilizer program.

Plant N Recovery. Percent N recovered by turfgrass during the experimental period ( 1 year) was calculated by dividing the plant $\mathrm{N}$ uptake by total $\mathrm{N}$ input for the whole year (Table 5 ). The source of $\mathrm{N}$ in the turfgrass with the control treatment irrigated by tap water was the $\mathrm{N}$ remaining in the sod and natural $\mathrm{N}$ input (e.g., atmospheric deposition). Plant $\mathrm{N}$ uptake in plants with the other treatments resulted from $\mathrm{N}$ in the RW, synthetic N, and atmospheric N. These amounts were calculated by subtracting the control turf $\mathrm{N}$ uptake from the total $\mathrm{N}$ uptake with each treatment. $\mathrm{N}$ recovery was in the range of $13 \%$ to $52 \%$ for st. augustinegrass and $21 \%$ to $84 \%$ for zoysiagrass overall $\mathrm{N}$ treatments (Table 5 ). The highest recovery for both turf types was found when the $\mathrm{N}$ solution was $9 \mathrm{mg} \cdot \mathrm{L}^{-1}$.

Reclaimed water with total $\mathrm{N}$ at 9 and $13 \mathrm{mg} \cdot \mathrm{L}^{-1}$ with $300 \mathrm{~mL} / \mathrm{tub}$ irrigation rate, resulted in total $\mathrm{N}$ amounts added monthly of 0.054 and $0.090 \mathrm{~g} / \mathrm{tub}$, respectively, which

Table 3. Effect of nitrogen treatments on dry weight accumulation of turfgrass plant parts. Multiple clippings from the same season were mixed for total Kjeldahl nitrogen analysis. Data are for the concentration in the composite of the dry matter mixture.

\begin{tabular}{|c|c|c|c|c|c|}
\hline $\begin{array}{l}\text { Clippings } \\
\text { (Fall 2011) }\end{array}$ & $\begin{array}{c}\text { Clippings } \\
\text { (Spring 2012) }\end{array}$ & $\begin{array}{c}\text { Clippings } \\
\text { (Summer 2012) }\end{array}$ & Verdure & Thatch & Root \\
\hline
\end{tabular}

\begin{tabular}{|c|c|c|c|c|c|c|}
\hline \multicolumn{7}{|c|}{$\begin{array}{l}\text { Nitrogen treatment } \\
\quad\left(\text { total nitrogen } \mathrm{mg} \cdot \mathrm{L}^{-1}\right)^{\mathrm{y}}\end{array}$} \\
\hline 0 & $13.7 c^{x}$ & $12.9 \mathrm{c}$ & $7.1 \mathrm{c}$ & $11.1 \mathrm{a}$ & $7.5 \mathrm{a}$ & $14.8 \mathrm{a}$ \\
\hline 3 & $15.9 \mathrm{c}$ & $18.6 \mathrm{~b}$ & $9.1 \mathrm{~b}$ & $16.6 \mathrm{a}$ & $6.5 \mathrm{a}$ & $12.4 \mathrm{a}$ \\
\hline 9 & $27.7 \mathrm{a}$ & $29.9 \mathrm{ab}$ & $12.9 \mathrm{~b}$ & $15.9 \mathrm{a}$ & $6.4 \mathrm{a}$ & $11.0 \mathrm{a}$ \\
\hline 13 & $29.5 \mathrm{a}$ & $27.2 \mathrm{ab}$ & $12.9 \mathrm{~b}$ & $16.4 \mathrm{a}$ & $7.9 \mathrm{a}$ & $16.7 \mathrm{a}$ \\
\hline Recommended & $29.4 \mathrm{a}$ & $32.5 \mathrm{a}$ & $17.3 \mathrm{a}$ & $16.1 \mathrm{a}$ & $5.6 \mathrm{a}$ & $8.3 \mathrm{a}$ \\
\hline \multicolumn{7}{|l|}{ Turf type } \\
\hline St. augustinegrass & 23.0 & 18.8 & 8.0 & 9.1 & 4.8 & 9.7 \\
\hline Zoysiagrass & 20.7 & 33.6 & 16.3 & 22.6 & 9.5 & 15.6 \\
\hline \multicolumn{7}{|c|}{ Summary of ANOVA effects ${ }^{w}$} \\
\hline Turf $(\mathrm{T})$ & NS & ** & ** & ** & * & * \\
\hline $\mathrm{N}$ treatment $(\mathrm{N})$ & $* * *$ & ** & * & NS & NS & NS \\
\hline
\end{tabular}

${ }^{2} 1 \mathrm{~g}$ per $1386-\mathrm{cm}^{2}\left(214.8 \mathrm{inch}^{2}\right) \mathrm{tub}=7.2150 \mathrm{~g} \cdot \mathrm{m}^{-2}=0.2128 \mathrm{oz} / \mathrm{yard}^{2}$

${ }^{y}$ Nitrogen treatment include irrigation with reclaimed water with additional nitrogen supplied from ammonium nitrate to achieve 5 , 9 , and 13 mg. $\mathrm{L}^{-1}$ nitrogen solutions, and with the recommended synthetic fertilizer treatment received the equivalent of $195 \mathrm{~kg} \cdot \mathrm{ha}^{-1}(174.0 \mathrm{lb} / \mathrm{acre})$ nitrogen per year; $1 \mathrm{mg} \cdot \mathrm{L}^{-1}=1 \mathrm{ppm}$

${ }^{x}$ Values within a column by the same letter do not differ at $P=0.05$.

wNs, ${ }^{*},{ }^{* *},{ }^{* \star *}$ Nonsignificant or significant at $P<0.05,0.01$, or 0.001 , respectively. 
Table 4. Effects of treatment on plant tissue total Kjeldahl nitrogen concentration of turfgrass. Multiple clippings from the same season were mixed for Total Kjeldahl nitrogen analysis. Data are for the concentration in the composite of the dry matter.

\begin{tabular}{|c|c|c|c|c|c|}
\hline $\begin{array}{l}\text { Clippings } \\
\text { (Fall 2011) }\end{array}$ & $\begin{array}{c}\text { Clippings } \\
\text { (Spring 2012) }\end{array}$ & $\begin{array}{c}\text { Clippings } \\
\text { (Summer 2012) }\end{array}$ & Thatch & Root & Verdure \\
\hline
\end{tabular}

\begin{tabular}{|c|c|c|c|c|c|c|}
\hline \multicolumn{7}{|l|}{$\begin{array}{l}\text { Nitrogen treatment } \\
\quad\left(\text { total nitrogen } \mathrm{mg} \cdot \mathrm{L}^{-1}\right)^{\mathrm{y}}\end{array}$} \\
\hline 0 & $15.3 b^{x}$ & $13.2 \mathrm{~b}$ & $14.3 \mathrm{~b}$ & $5.9 \mathrm{~b}$ & $8.68 \mathrm{a}$ & $6.9 \mathrm{~b}$ \\
\hline 3 & $16.3 \mathrm{~b}$ & $12.7 \mathrm{~b}$ & $14.9 \mathrm{~b}$ & $6.5 \mathrm{ab}$ & $8.4 \mathrm{a}$ & $7.7 \mathrm{a}$ \\
\hline 9 & $18.9 \mathrm{a}$ & $17.4 \mathrm{a}$ & $15.4 \mathrm{ab}$ & $6.8 \mathrm{~b}$ & $8.5 \mathrm{a}$ & $7.8 \mathrm{a}$ \\
\hline 13 & $21.1 \mathrm{a}$ & $15.9 \mathrm{a}$ & $15.8 \mathrm{a}$ & $7.57 \mathrm{~b}$ & $7.6 \mathrm{a}$ & $7.8 \mathrm{a}$ \\
\hline Recommended & $19.1 \mathrm{a}$ & $15.7 \mathrm{a}$ & $15.7 \mathrm{a}$ & $7.2 \mathrm{~b}$ & $7.7 \mathrm{a}$ & $8.5 \mathrm{a}$ \\
\hline \multicolumn{7}{|l|}{ Turf type } \\
\hline St. augustinegrass & 19.5 & 11.8 & 15.4 & 6.6 & 9.7 & 7.1 \\
\hline Zoysiagrass & 16.8 & 17.1 & 15.3 & 6.9 & 6.4 & 8.2 \\
\hline \multicolumn{7}{|c|}{ Summary of ANOVA effects ${ }^{w}$} \\
\hline Turf $(\mathrm{T})$ & * & ** & NS & NS & ** & * \\
\hline $\mathrm{N}$ treatment $(\mathrm{N})$ & ** & ** & ** & * & NS & $* *$ \\
\hline
\end{tabular}

${ }^{\mathrm{z}} \mathrm{l} \mathrm{mg} \cdot \mathrm{g}^{-1}=1000 \mathrm{ppm}$.

${ }^{y}$ Nitrogen treatment include irrigation with reclaimed water with additional $\mathrm{N}$ supplied from ammonium nitrate to achieve 5,9 , and 13 mg $\cdot \mathrm{L}^{-1}$ nitrogen solutions, and with the recommended synthetic fertilizer treatment received the equivalent of $195 \mathrm{~kg} \cdot \mathrm{ha} \mathrm{a}^{-1}(174.0 \mathrm{lb} / \mathrm{acre})$ nitrogen per year; $1 \mathrm{mg} \cdot \mathrm{L}^{-1}=1 \mathrm{ppm}$.

Values within a column with the same letter do not differ at $P=0.05$.

wNs, ${ }^{*},{ }^{* *},{ }^{* \star *}$ Nonsignificant or significant at $P<0.05,0.01$, or 0.001 , respectively.
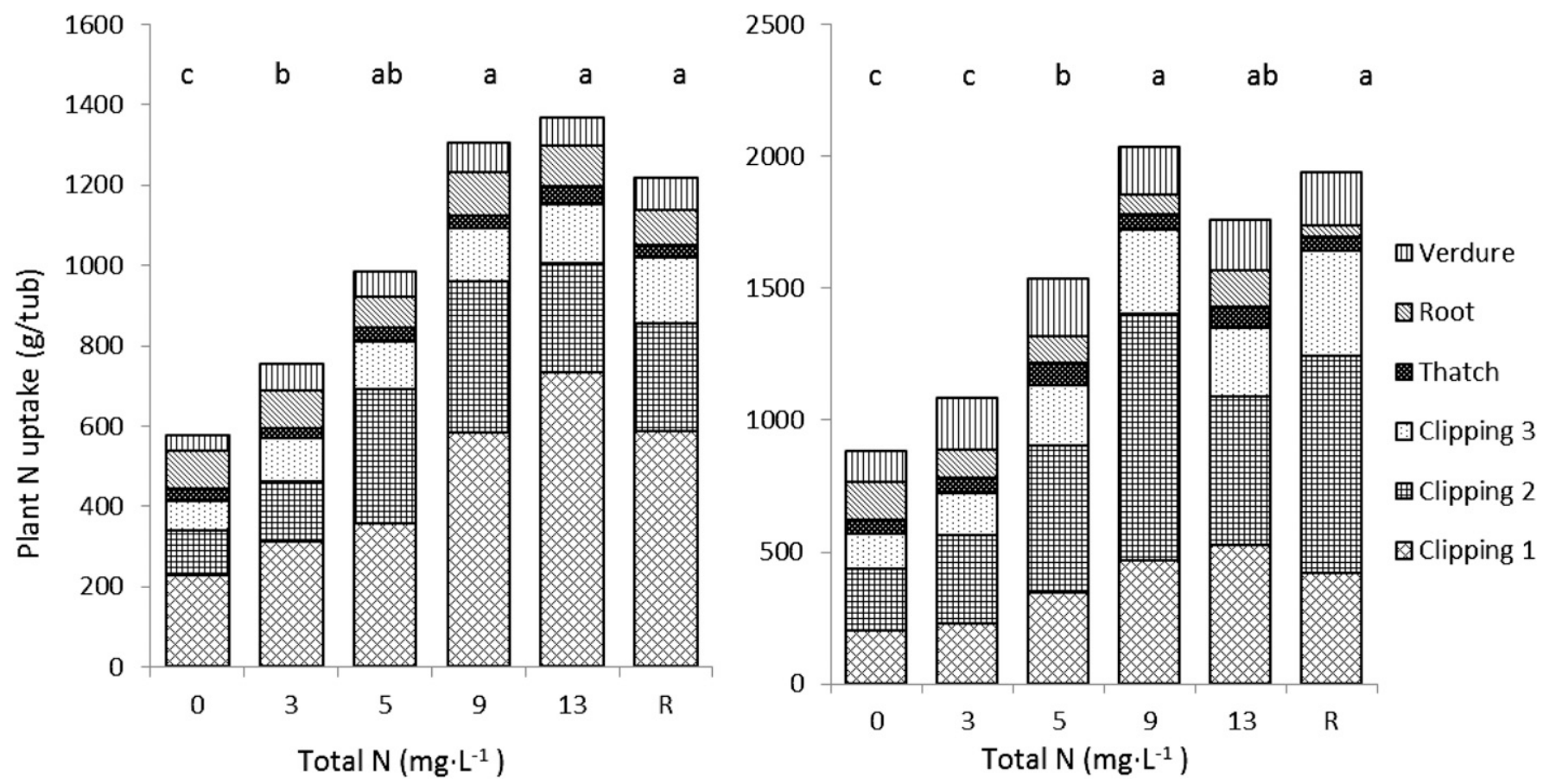

Fig. 3. Turfgrass nitrogen $(\mathrm{N})$ uptake under different fertilizer treatments for st. augustinegrass (left) and zoysiagrass (right). Letter " $\mathrm{R}$ " for $\mathrm{N}$ treatment refers to a dry fertilizer treatment based on the recommended $\mathrm{N}$ application rate for turfgrass in northern Florida. Clippings 1-3 refer to clipping collected in the season of Fall 2011, Spring 2012, and Summer 2012, respectively. Values are averages of four replicates of each treatment. Means for total plant uptake with the same letters are not significantly different by Fisher's least significant difference $0.05 ; 1 \mathrm{~g}$ per $1386-\mathrm{cm}^{2}\left(214.8 \mathrm{inch}^{2}\right)$ tub $=7.2150 \mathrm{~g} \cdot \mathrm{m}^{-2}=0.2128 \mathrm{oz} / \mathrm{yard}$.

was less than half of that added from the recommended rate of synthetic fertilizer $(0.227 \mathrm{~g} \mathrm{~N})$. Turfgrass used the $\mathrm{N}$ in $\mathrm{RW}$ and achieved acceptable quality with total $\mathrm{N}$ at 9 and 13 $\mathrm{mg} \cdot \mathrm{L}^{-1}$. Our results show that $\mathrm{N}$ contained in RW can be a significant source of $\mathrm{N}$ for turfgrass nutrition.
N LEACHING FROM TURFGRASS. Reclaimed water is a dilute nutrient solution; therefore, $\mathrm{N}$ can be leached under excessive application rates of 
Table 5. Effects of turfgrass type and nitrogen $(\mathrm{N})$ treatment on $\mathrm{N}$ recovery for the whole year.

\begin{tabular}{|c|c|c|c|c|c|c|}
\hline \multirow{3}{*}{$\begin{array}{l}\text { N treatment } \\
\left(\text { total } \mathrm{N} \mathrm{mg} \cdot \mathrm{L}^{-1}\right)^{\mathrm{z}}\end{array}$} & \multirow[b]{2}{*}{$\begin{array}{l}\text { Plant N } \\
\text { content }\end{array}$} & \multirow[b]{2}{*}{$\begin{array}{l}\text { Plant } \mathrm{N} \text { uptake from } \\
\text { anthropogenic input }\end{array}$} & \multicolumn{3}{|c|}{$\mathrm{N}$ anthropogenic input } & \multirow{3}{*}{$\frac{\text { Recovery }^{\mathrm{y}}}{\%}$} \\
\hline & & & Fertilizer & $\begin{array}{c}\text { Reclaimed } \\
\text { water source }\end{array}$ & Total & \\
\hline & \multicolumn{5}{|c|}{ - } & \\
\hline \multicolumn{7}{|l|}{ St. augustinegrass } \\
\hline 0 & $580^{\mathrm{z}}$ & 0 & 0 & 0 & 0 & - \\
\hline 3 & 760 & 180 & 0 & 420 & 420 & $43 b^{w}$ \\
\hline 13 & 1,410 & 830 & 0 & 2,220 & 2,220 & $37 \mathrm{~b}$ \\
\hline Recommended & 1,220 & 640 & $4,990^{\mathrm{v}}$ & 0 & 4,990 & $13 \mathrm{c}$ \\
\hline \multicolumn{7}{|l|}{ Zoysiagrass } \\
\hline 0 & $880^{\mathrm{z}}$ & 0 & 0 & 0 & 0 & - \\
\hline 3 & 1,090 & 200 & 0 & 420 & 420 & $49 \mathrm{~b}$ \\
\hline 5 & 1,540 & 660 & 0 & 780 & 780 & $84 \mathrm{a}$ \\
\hline
\end{tabular}

${ }^{2}$ Control treatment $\mathrm{N}$ from the original turf plant and atmospheric $\mathrm{N}$ deposition; $1 \mathrm{mg} \cdot \mathrm{L}^{-1}=1 \mathrm{ppm}$.

y Plant $\mathrm{N}$ uptake from anthropogenic input being divided by the $\mathrm{N}$ anthropogenic input year for a whole year.

${ }^{x} 1 \mathrm{mg}$ per $1386-\mathrm{cm}^{2}\left(214.8\right.$ inch $\left.^{2}\right)$ tub $=7.2150 \mathrm{mg} \cdot \mathrm{m}^{-2}=1.0299 \mathrm{oz} /$ acre .

walues within a column with the same letter do not differ at $P=0.05$.

${ }^{\mathrm{N}} \mathrm{N}$ application as $195 \mathrm{~kg} \cdot \mathrm{ha}^{-1}(174.0 \mathrm{lb} / \mathrm{acre})$ nitrogen per year.

Table 6. Effect of treatments on nitrogen loads in leachate in two leaching events

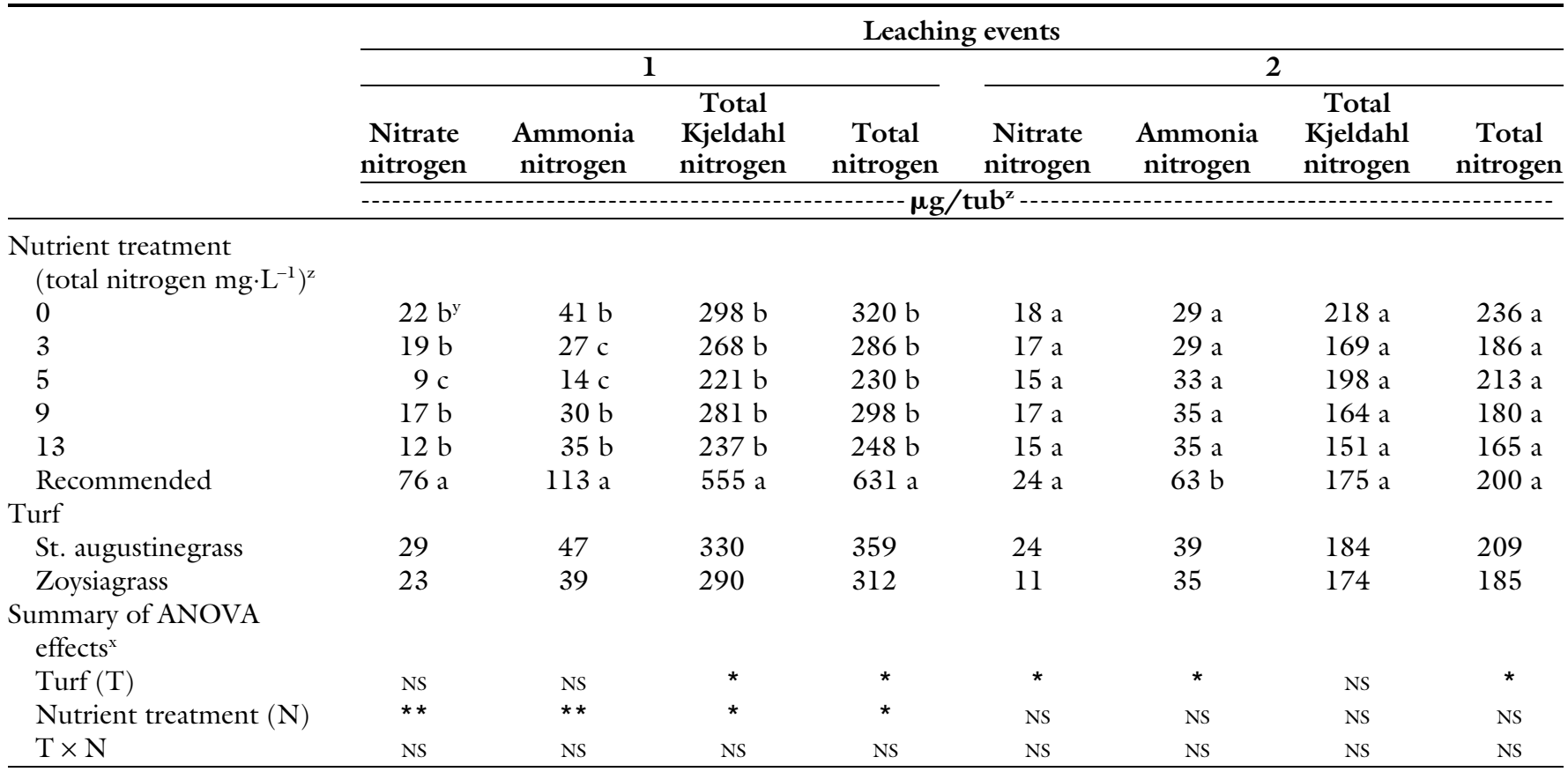

${ }^{\mathrm{z}} 1 \mathrm{mg} \cdot \mathrm{L}^{-1}=1 \mathrm{ppm}, 1 \mu \mathrm{g}$ per $1386-\mathrm{cm}^{2}\left(214.8 \mathrm{inch}^{2}\right) \mathrm{tub}=7.2150 \mu \mathrm{g} \cdot \mathrm{m}^{-2}=0.0010 \mathrm{oz} / \mathrm{acre}$.

values within a column by the same letter do not differ at $P=0.05$.

xNs, ${ }^{*},{ }^{* *}$ Nonsignifcant or significant at $P<0.05$ or 0.01 , respectively.

RW. Two leaching events were applied near the conclusion of this experiment in Aug. 2012 to test the hypothesis that amounts of leached $\mathrm{N}$ will be similar with various irrigation rates. Leachate $\mathrm{N}$ loads were determined by multiplying the concentration of $\mathrm{N}$ in the leachate from each tub with the leachate volume (Table 6).
There was no interaction between $\mathrm{N}$ treatment and turf type for effects on amounts of leached N. Nitrogen treatment affected the total $\mathrm{N}$ loads for the first leaching event. More N was lost with the synthetic fertilizer treatment compared with all other $\mathrm{N}$ treatments. There were no differences in $\mathrm{N}$ lost among the tap water and all
RW treatments. The total $\mathrm{N}$ loss with synthetic $\mathrm{N}$ was 2 -fold the $\mathrm{N}$ lost with the remaining treatments for the first leaching event. Perhaps more N was lost with the synthetic $\mathrm{N}$ treatment because more $\mathrm{N}$ was applied in monthly applications compared with small daily amounts with the RW treatments. Greater amounts of residual 
$\mathrm{N}$ were available for leaching with the synthetic treatment. The differences in $\mathrm{N}$ leached between $\mathrm{N}$ treatments for the second leaching event were not significant. In both leaching tests, more $\mathrm{N}$ was lost from st. augustinegrass compared with zoysiagrass. The length of time between fertilizer applications and leaching rainfall or irrigation determines the extent of nutrient losses from turfgrass systems (Petrovic and Easton, 2005). In the current study, $\mathrm{N}$ inputs from $\mathrm{RW}$ receiving advanced treatment were negligible. Hayes et al. (1990a) conducted a study on irrigation of turfgrass with RW receiving secondary treatment and found that elemental concentrations in leachate increased when the RW contained significant amounts of $\mathrm{NH}_{4}-\mathrm{N}$ (up to $28.6 \mathrm{mg} \cdot \mathrm{L}^{-1}$ ).

\section{Conclusions}

$\mathrm{N}$ concentrations in the RW varied throughout the year, so that calculations of fertilizer offsets will need to take into account these variations. Turfgrass produced more biomass and took up more $\mathrm{N}$ in response to increased $\mathrm{N}$ delivery. There was no difference in turfgrass growth with the base level $\mathrm{N}$ in the delivered $\mathrm{RW}$ compared with tap water. As more N was added to the base RW, turfgrass growth increased. Similar growth resulted from RW with 9 or $13 \mathrm{mg} \cdot \mathrm{L}^{-1}$ total $\mathrm{N}$ compared with monthly applications of the current recommended commercial fertilizer $\mathrm{N}$ rate in northern Florida. Although growth was increased as $\mathrm{N}$ concentration in the RW increased from 5 to $9 \mathrm{mg} \cdot \mathrm{L}^{-1}$, turfgrass quality (color) was acceptable with $5 \mathrm{mg} \cdot \mathrm{L}^{-1}$ total $\mathrm{N}$. The $\mathrm{N}$ concentrations in RW from advanced wastewater treatment facilities in the current study were too low $\left(3 \mathrm{mg} \cdot \mathrm{L}^{-1}\right.$ N) to benefit turfgrass and achieve acceptable quality. A RW facility producing $\mathrm{RW}$ with $5 \mathrm{mg} \cdot \mathrm{L}^{-1}$ or above would provide enough $\mathrm{N}$ for a response in turfgrass growth reducing the need for fertilizer. Leaching of $\mathrm{N}$ was unaffected by RW treatment, but more $\mathrm{N}$ was leached with the synthetic fertilizer treatment compared with RW. Leaching of $\mathrm{N}$ with all treatments was negligible. These greenhouse studies show that $\mathrm{N}$ from RW can be beneficial for turfgrass growth and health but the concentration of $\mathrm{N}$ in RW with advanced treatment would need to be at least $5 \mathrm{mg} \cdot \mathrm{L}^{-1}$. Outdoor field-scale experiments are needed to validate the results from these greenhouse studies.

\section{Literature cited}

Asano, T., F.L. Burton, H.L. Leverenz, R. Tsuchihashi, and G. Tchobanoglous. 2007. Water reuse: Issues, technologies, and applications. McGraw Hill, New York, NY.

Bowman, D.C., C.T. Cherney, and T.W. Rufty. Jr. 2002. Fate and transport of nitrogen applied to six warm-season turfgrasses. Crop Sci. 42:833-841.

Carrow, R.N. 2012. Turfgrass nutrition and irrigation water quality. Commun. Soil Sci. Plant Nutr. 43:451-463.

Carrow, R.N. and R.R. Duncan. 1998. Saltaffected turfgrass sites: Assessment and management. Ann Arbor Press, Chelsea, MI.

Errecart, P.M., M.G. Agnusdei, F.A. Lattanzi, and M.A. Marino. 2012. Leaf nitrogen concentration and chlorophyll meter readings as predictors of tall fescue nitrogen nutrition status. Field Crops Res. 129(11):46-58.

Evanylo, G., E. Ervin, and X. Zhang. 2010. Reclaimed water for turfgrass irrigation. Water 2:685-701.

Exall, K., J. Marsalek, and K. Schaefer. 2004. A review of water reuse and recycling, with reference to Canadian practice and potential: 1 . Incentives and implementation. Water Qual. Res. J. Canada 1:1-12.

Harivandi, M.A. 2004. A review of sports turf irrigation with municipal recycled water. Acta Hort. 661:131-136.

Hayes, A.R., C.F. Mancino, and I.L. Pepper. 1990a. Irrigation of turfgrass with secondary sewage effluent: I. Soil and leachate water quality. Agron. J. 82:939-943.

Hayes, A.R., C.F. Mancino, and I.L. Pepper. 1990b. Irrigation of turfgrass with secondary sewage effluent: II. Turf quality. Agron. J. 82:943-946.

Hochmuth, G., T. Nell, J. Sartain, B. Unruh, M. Dukes, C. Martinez, L. Trenholm, and J. Cisar. 2009. Potential unintended consequences associated with urban fertilizer bans in Florida:A scientific review. HortTechnology 22:600-616.

Kalavrouziotis, I.K., P. Robolas, P.H. Koukoulakis, and A.H. Papadopoulos. 2008. Effects of municipal reclaimed wastewater on the macro- and microelements status of soil and of Brassica oleracea var. Italica, and B. oleracea var. Gemmifera. Agr. Water Mgt. 95:419-426.

King, K.W. and J.C. Balogh. 1999. Modeling evaluation of alternative management practices and reclaimed water for turfgrass systems. J. Environ. Qual. 28:187-193.

Kruse, J.K., N.E. Christians, and M.H. Chaplin. 2006. Remote sensing of nitrogen stress in creeping bentgrass. Agron. J. 98:1640-1645.

Maurer, M.A., F.S. Davies, and D.A. Graetz. 1995. Reclaimed wastewater irrigation and fertilization of mature 'Redblush' grapefruit trees. J. Amer. Soc. Hort. Sci. 120:394-402.

Mehlich, A. 1984. Mehlich 3 soil test extractant: A modification of Mehlich 2 extractant. Commun. Soil Sci. Plant Nutr. 15:1409-1416.

O'Connor, G.A., H.A. Elliott, and R.K. Bastian. 2008. Degraded water reuse: An overview. J. Environ. Qual. 37:157168.

Pedrero, F. and J.J. Alarcon. 2009. Effects of treated wastewater irrigation on lemon trees. Desalination 246:631-639.

Pereira, B.F.F., Z.L. He, P.J. Stoffella, and A.J. Melfi. 2011. Reclaimed wastewater: Effects on citrus nutrition. Agr. Water Mgt. 98:1828-1833.

Pereira, B.F.F., Z.L. He, P.J. Stofella, C.R. Montes, A.J. Melfi, and V.C. Baligar. 2012. Nutrients and nonessential elements in soil after 11 years of wastewater irrigation. J. Environ. Qual. 41:920-927.

Petrovic, A.M. 1990. The fate of nitrogenous fertilizers applied to turfgrass. J. Environ. Qual. 19:1-14.

Petrovic, A.M. and Z.M. Easton. 2005. The role of turfgrass management in the water quality of urban environments. Intl. Turfgrass Soc. Res. J. 10:55-69.

Rowland, J.H., J.L. Cisar, G.H. Snyder, J.B. Sartain, A.L. Wright, and J.E. Erickson. 2010. Optimal nitrogen and potassium fertilization rates for establishment of warm-season putting greens. Agron. J. 102:1601-1605.

Sartain, J.B. 2001. Soil and tissue testing and interpretation for Florida turfgrasses. Florida Coop. Ext. Serv. SL 181.

Saxton, K.E. and W.J. Rawls. 2006. Soil water characteristic estimates by texture and organic matter for hydrologic solutions. Soil Sci. Soc. Amer. J. 70:15691578.

Sevostianova, E., B. Leinauer, R. Sallenave, D. Karcher, and B. Maier. 2011a. Soil salinity and quality of sprinkler and drip irrigated cool-season turfgrasses. Agron. J. 103:1503-1513.

Sevostianova, E., B. Leinauer, R. Sallenave, D. Karcher, and B. Maier. 2011b. Soil salinity and quality of sprinkler and drip 


\section{Research Reports}

irrigated warm-season turfgrasses. Agron. J. 103:1773-1784.

Sun, G., S.G. McNulty, J.A.M. Myers, and E.C. Cohen. 2008. Impacts of multiple stresses on water demand and supply across the southeastern United States. J. Amer. Water Resources Assn. 44:14411457.

Thomas, J.C., R.H. White, J.T. Vorheis, H.G. Harris, and K. Diehl. 2006. Environmental impact of irrigating turf with Type I recycled water. Agron. J. 98:951961.

Toor, G.S. and D.P. Rainey. 2009. History and current status of reclaimed water use in Florida. Florida Coop. Ext. Serv. SL 308.

Trenholm, L.E. 2009. Establishing your Florida lawn. Florida Coop. Ext. Serv. ENH-03.
Trenholm, L.E., J.B. Unruh, and J.B. Sartain. 2012. Nitrate leaching and turf quality in established 'Floratam' st. augustinegrass and 'Empire' zoysiagrass. J. Environ. Qual. 41:793-799.

U.S. Department of Agriculture. 2010. Fertilizers use and price; Average U.S. farm prices of selected fertilizers. 20 Oct. 2012. <http://www.ers.usda.gov/ data-products/fertilizer-use-and-price.aspx $>$.

U.S. Environmental Protection Agency. 1993a. Method 351.2. Determination of total Kjeldahl nitrogen by semiautomated colorimetry. Revision 2.0. U.S. Environ. Protection Agency, Cincinnati, $\mathrm{OH}$.

U.S. Environmental Protection Agency. 1993b. Method 365.1. Determination of phosphorus by semi-automated colorimetry,
Revision 2.0. U.S. Environ. Protection Agency, Cincinnati, $\mathrm{OH}$.

U.S. Environmental Protection Agency. 1994. Method 200.7. Determination of metals and trace elements in water and waste, Revision 4.4. U.S. Environ. Protection Agency, Cincinnati, $\mathrm{OH}$

Wang, Z., A.C. Chang, L. Wu, and D. Crowley. 2003. Assessing the soil quality of long-term reclaimed wastewater-irrigated cropland. Geoderma 114:261-278.

Xu, J., W. Chen, L. Wu, R. Green, and A.C. Chang. 2009. Leachability of some emerging contaminants in reclaimed municipal wastewater irrigated turf grass fields. Environ. Toxicol. Chem. 28:18421850 .

Xu, J., W. Laosheng, A.C. Chang, and Y. Zhang. 2010. Impact of long-term reclaimed wastewater irrigation on agricultural soils: A preliminary assessment. J. Hazard. Mater. 183:780-786. 